\title{
First Report of Stemphylium vesicarium Causing Onion Stemphylium Leaf Blight in Ethiopia
}

\author{
Yitayih Gedefaw*, Abebe Gezahegn, Abiy Fekadu, Zeraye Mehari \\ Department of Plant Pathology, Ethiopian Institute of Agricultural Research (EIAR), Melkassa Agricultural Research Center (MARC), \\ Adama, Ethiopia \\ Email: *yitayihg@gmail.com
}

How to cite this paper: Gedefaw, Y., Gezahegn, A., Fekadu, A. and Mehari, Z. (2019) First Report of Stemphylium vesicarium Causing Onion Stemphylium Leaf Blight in Ethiopia. Agricultural Sciences, 10, 1104-1112.

https://doi.org/10.4236/as.2019.108083

Received: July 5, 2019

Accepted: August 25, 2019

Published: August 28, 2019

Copyright (c) 2019 by author(s) and Scientific Research Publishing Inc. This work is licensed under the Creative Commons Attribution International License (CC BY 4.0).

http://creativecommons.org/licenses/by/4.0/

\begin{abstract}
A suspected fungal disease was observed on onion leaves during survey in onion fields of the central rift valley of Ethiopia in the offseason in 2019. The disease symptoms were round to oval small spots on onion leaves which coalesce to form blighted leaves that change to brown lesion and black sporulation with time. The disease was of high incidence (up to 95.2\%) and severity (up to 4.67) where in some fields it has been causing early plant senescence and reduced bulb size during harvest with massive yield loss, named to be "Yeshinkurt Ebola" to mean "Ebola of onion" by farmers. Dirty white to light grey front colony color and light brown to deep brown reverse colony color with alternative white and brown band fungal growth were isolated from infected onion leaf samples. The conidia were olive brown, oval to ovoid, oblong and ovoid to oblong are born on conidiophores. Pathogenicity of the pathogen was confirmed on 45-days-old onion (cv. Nafis) plant, and it was identified as Stemphylium vesicarium based on cultural, morphological and pathogenic results. This is the first report of $S$. vesicarium, the causative agent of onion stemphylium leaf blight.
\end{abstract}

\section{Keywords}

Stemphylium vesicarium, Onion, Prevalence, Severity, Pathogenicity

\section{Introduction}

Many small- and large-scale farmers in the main onion-producing areas of central rift valley of Ethiopia grow onion (Allium cepa L.). In total, 31,673 ha of land were covered by onion with 293,887.6 tonnes of production, CSA [1]. Nowadays, the area under onion production is increasing. However, its production and/or productivity is affected by many biotic (diseases, and insects pests) and abiotic like imbalanced fertilizer, uneven irrigation and inappropriate agro- 
nomic practices, Amin et al. [2]. Currently, a strange disease, expected to be stemphylium leaf blight is observed in farmers' field and research stations of the CRV.

Stemphylium leaf blight caused by Stemphylium vesicarium Wallr (Simmons) (teleomorph: Pleospora allii. (Rabenh.) Ces. and De Not) is one of the most destructive fungal diseases in Allium species. The host range of the pathogen varies among different crops such as garlic, Suheri and Price [3], chilli pepper, Vitale et al. [4], leek, Suheri and Price [3], asparagus, Foster [5], pear, Llorente and Montesinos [6] and Köhl et al. [7].

Stemphylium leaf blight was first identified from India in 1975 on garlic, Rao and Pavgi [8] and has subsequently been recorded in USA, Shishkoff and Lorbeer [9], South Africa, Aveling and Naude [10]; Aveling and Snyman [11], Spain, Basallote et al. [12], Brazil, Boiteux et al. [13] and Turkey, Polat et al. [14]. The genus Stemphylium comprises 28 phylogenetically distinguished plant pathogenic species, Woudenberg et al. [15]. Recently, Brahamanage et al. [16] reviewed the existence of the genus Stemphylium in the Netherlands, Bangladesh, Egypt, Nepal, Syria, and China on different host plants. Stemphylium vesicarium is considered as very disruptive disease, which can cause up to $90 \%$ yield losses on onion, Miller et al. [17]; Tomaz and Lima [18]; Lorbeer [19], 60 - 90\% yield loss on pear, Llorente and Montesinos [20], and complete spears loss on asparagus, Hausbeck et al. [21].

In Ethiopia, purple blotch (Alternaria porri) and downy mildew (Peronospora destructor) diseases are considered as the major constraints of onion production and productivity, Wondirad et al. [22]. Purple blotch is prevalent in all oniongrowing areas of the country. It attacks leaves, bulb and seed stalks and subsequently reduces yield and quality. Since 2018, however, a new disease symptom, which confuses with purple blotch disease, was observed in the central rift valley areas of Ethiopia. The disease typically attacks leaf, which starts with round to oval small spots that later coalesce to form blighting to leaf tissue. The lesion turns brown to tan, for some time; the disease was probably misdiagnosed as purple blotch since their symptoms are very similar. Samples submitted to the plant pathology laboratory of Melkassa Agricultural Research Center of Ethiopian Institute of Agricultural Research (EIAR) revealed the presence of stemphylium leaf blight (SLB).

Following the detection of the pathogen ( $S$. vesicarium) survey was conducted to have a clear picture of its prevalence, incidence and severity. The survey covered the main onion producing areas in the central rift valley (CRV) of Ethiopia. Cultural and morphological characteristics of symptomatic onion leaf samples of the survey indicated the existence SLB disease ( $S$. vesicarium).

\section{Materials and Methods}

\subsection{Description of the Study Area}

The field survey was conducted during the 2019 cropping season. The survey 
encompassed a total of 26 onion fields in the five districts (Adama, Bora, Dugda, Jeju and Lumie) of the CRV (located $08^{\circ} 00^{\prime} 10.6^{\prime \prime}$ to $08^{\circ} 30^{\prime} 01.7^{\prime \prime} \mathrm{N}, 038^{\circ} 43^{\prime} 53.9^{\prime \prime}$ to $039^{\circ} 35^{\prime} 21.8^{\prime \prime}$ E) of Ethiopia (Table 1). Characteristic features of surveyed onion fields were summarized in Table 2.

\subsection{Sampling and Sampling Units}

Fields were ordinarily selected at intervals of $5-10 \mathrm{~km}$ along the main roads. When necessary, the sample sizes (the number of observed fields per district) and the distance between sample units (the arbitrarily selected quadrants, 5 - 10) per field were adjusted to suit crop distribution and field-size. All sampled fields

Table 1. Descriptions of surveyed onion fields and associated disease pressure in the Central Rift Valley of Ethiopia (Jan. 14-18, 2019).

\begin{tabular}{|c|c|c|c|c|c|c|c|c|c|c|}
\hline ID & District & Locality & Var. & Alt (masl) & Latitude (N) & Longitude (E) & DAT & DI & DS & YFFO \\
\hline 1 & Jeju & HD & $\mathrm{BR}$ & 1258 & $08^{\circ} 30^{\prime} 01.7^{\prime \prime}$ & $039^{\circ} 34^{\prime} 24.1^{\prime \prime}$ & 75 & 87.5 & 4 & 2017 \\
\hline 2 & Jeju & HD & $\mathrm{BR}$ & 1267 & $08^{\circ} 29^{\prime} 49.1^{\prime \prime}$ & $039^{\circ} 34^{\prime} 30.1^{\prime \prime}$ & 90 & 75 & 3 & 2017 \\
\hline 3 & Jeju & $\mathrm{HD}$ & $\mathrm{BR}$ & 1256 & $08^{\circ} 29^{\prime} 45.6^{\prime \prime}$ & $039^{\circ} 34^{\prime} 20.1^{\prime \prime}$ & 67 & 72.5 & 3 & 2017 \\
\hline 4 & Jeju & HD & $\mathrm{BR}$ & 1253 & $08^{\circ} 29^{\prime} 49.5^{\prime \prime}$ & $039^{\circ} 34^{\prime} 22.5^{\prime \prime}$ & 60 & 72.5 & 2 & NI \\
\hline 5 & Jeju & HD & $\mathrm{BR}$ & 1270 & $08^{\circ} 29^{\prime} 32.1^{\prime \prime}$ & $039^{\circ} 35^{\prime} 21.8^{\prime \prime}$ & 90 & 95.2 & 4 & 2018 \\
\hline 6 & Jeju & HD & $\mathrm{BR}$ & 1268 & $08^{\circ} 29^{\prime \prime} 34.7^{\prime \prime}$ & $039^{\circ} 35^{\prime} 19.9^{\prime \prime}$ & 70 & 75 & 4 & 2018 \\
\hline 7 & Adama & $\mathrm{Ml}$ & $\mathrm{BR}$ & 1477 & $08^{\circ} 24^{\prime} 10.8^{\prime \prime}$ & $039^{\circ} 21^{\prime} 42.8^{\prime \prime}$ & 51 & 10 & 2 & 2017 \\
\hline 8 & Lumie & Koka & BR & 1598 & $08^{\circ} 27^{\prime} 19.7^{\prime \prime}$ & $039^{\circ} 01^{\prime} 39.7^{\prime \prime}$ & 60 & 93 & 2 & 2017 \\
\hline 9 & Lumie & Koka & $\mathrm{BR}$ & 1601 & $08^{\circ} 27^{\prime} 14.4^{\prime \prime}$ & $039^{\circ} 01^{\prime} 33.8^{\prime \prime}$ & 45 & 40.8 & 2.33 & NI \\
\hline 10 & Lumie & Koka & $\mathrm{BR}$ & 1595 & $08^{\circ} 27^{\prime} 08.9^{\prime \prime}$ & $039^{\circ} 01^{\prime} 29.4^{\prime \prime}$ & 60 & 72.7 & 2.75 & 2016 \\
\hline 11 & Lumie & Koka & $\mathrm{BR}$ & 1591 & $08^{\circ} 27^{\prime} 01.9^{\prime \prime}$ & $039^{\circ} 01^{\prime} 26.7^{\prime \prime}$ & 70 & 94.7 & 3 & 2017 \\
\hline 12 & Lumie & Koka & $\mathrm{BR}$ & 1607 & $08^{\circ} 21^{\prime} 51.2^{\prime \prime}$ & $038^{\circ} 59^{\prime} 51.2^{\prime \prime}$ & 70 & 36.4 & 2.33 & 2017 \\
\hline 13 & Lumie & Koka & $\mathrm{BR}$ & 1598 & $08^{\circ} 21^{\prime} 36.0^{\prime \prime}$ & $038^{\circ} 59^{\prime} 55.8^{\prime \prime}$ & 90 & 46.7 & 2.33 & 2017 \\
\hline 14 & Bora & Kenteri & $\mathrm{BR}$ & 1604 & $08^{\circ} 20^{\prime} 33.5^{\prime \prime}$ & $038^{\circ} 59^{\prime \prime} 14.6^{\prime \prime}$ & 67 & 28.37 & 2.33 & NI \\
\hline 15 & Bora & Kenteri & $\mathrm{BR}$ & 1601 & $08^{\circ} 20^{\prime} 02.6^{\prime \prime}$ & $038^{\circ} 58^{\prime} 56.1^{\prime \prime}$ & 70 & 20.01 & 2 & NI \\
\hline 16 & Bora & Elen & $\mathrm{BR}$ & 1654 & $08^{\circ} 20^{\prime} 05.4^{\prime \prime}$ & $038^{\circ} 56^{\prime \prime} 31.4^{\prime \prime}$ & 35 & 32.47 & 2 & NI \\
\hline 17 & Bora & Elen & $\mathrm{BR}$ & 1599 & $08^{\circ} 20^{\prime} 27.8^{\prime \prime}$ & $038^{\circ} 56^{\prime} 22.6^{\prime \prime}$ & 66 & 23.27 & 2.33 & 2016 \\
\hline 18 & Dugda & KA & $\mathrm{BR}$ & 1627 & $08^{\circ} 06^{\prime} 47.5^{\prime \prime}$ & $038^{\circ} 47^{\prime} 45.2^{\prime \prime}$ & 30 & 20.75 & 2 & NI \\
\hline 19 & Dugda & KA & $\mathrm{BR}$ & 1629 & $08^{\circ} 06^{\prime} 47.7^{\prime \prime}$ & $038^{\circ} 47^{\prime} 36.9^{\prime \prime}$ & 90 & 87.18 & 4.33 & NI \\
\hline 20 & Dugda & KA & $\mathrm{BR}$ & 1651 & $08^{\circ} 06^{\prime} 43.5^{\prime \prime}$ & $038^{\circ} 47^{\prime} 12.3^{\prime \prime}$ & 90 & 89.14 & 4.67 & 2018 \\
\hline 21 & Dugda & Abono & $\mathrm{BR}$ & 1666 & $08^{\circ} 04^{\prime} 30.7^{\prime \prime}$ & $038^{\circ} 45^{\prime} 03.9^{\prime \prime}$ & 33 & 33.7 & 2 & NI \\
\hline 22 & Dugda & $\mathrm{EC}$ & $\mathrm{BR}$ & 1633 & $08^{\circ} 00^{\prime} 22.1^{\prime \prime}$ & $038^{\circ} 43^{\prime} 54.9^{\prime \prime}$ & 60 & 50.18 & 3 & 2018 \\
\hline 23 & Dugda & $\mathrm{EC}$ & $\mathrm{BR}$ & 1626 & $08^{\circ} 00^{\prime} 10.6^{\prime \prime}$ & $038^{\circ} 43^{\prime} 53.9^{\prime \prime}$ & 90 & 41.67 & 3.33 & 2018 \\
\hline 24 & Dugda & Alemtena & $\mathrm{BR}$ & 1608 & $08^{\circ} 19^{\prime} 4.6^{\prime \prime}$ & $038^{\circ} 58^{\prime} 8.6^{\prime \prime}$ & 90 & 22.42 & 2.33 & 2018 \\
\hline 25 & Adama & $\mathrm{Ml}$ & $\mathrm{BR}$ & 1542 & $08^{\circ} 24^{\prime} 36.7^{\prime \prime}$ & $039^{\circ} 19^{\prime} 32.5^{\prime \prime}$ & 70 & 82.5 & 3 & NI \\
\hline 26 & Adama & $\mathrm{Ml}$ & Nafis & 1534 & $08^{\circ} 24^{\prime} 23.6^{\prime \prime}$ & $039^{\circ} 19^{\prime} 56.6^{\prime \prime}$ & 80 & 82.5 & 3 & NI \\
\hline
\end{tabular}

Where, Var: variety; Alt: altitude; DAT: days after transplanting (days); DI: disease incidence; DS: disease severity; HD: Horota Dore; Ml: Melkassa; KA: Korki Adi; EC: Elka Chelemo; BR:Bombe red; NI: no idea and YFFO: year of farmers first observation. 
Table 2. Characteristic features of surveyed onion fields in the Central Rift Valley, Ethiopia.

\begin{tabular}{ccccc}
\hline District & Altitude (m.a.s.l) & $\begin{array}{c}\text { Temperature } \\
\text { range }\left({ }^{\circ} \mathrm{C}\right)\end{array}$ & $\begin{array}{c}\text { Relative Humidity } \\
\text { range (\%) }\end{array}$ & $\begin{array}{c}\text { Cropping } \\
\text { system }^{\mathrm{a}}\end{array}$ \\
\hline Dugda & $1608.5-1666$ & $20.55-31.75$ & $37.55-73.25$ & sole \\
Bora & $1599-1654$ & $28.90-38.90$ & $33.10-60.25$ & sole \\
Lumie & $1591-1607$ & $26.70-34.40$ & $28.95-46.30$ & sole \\
Adama & $1477-1542$ & $24.10-29.85$ & $31.50-58.30$ & sole \\
Jeju & $1253-1270$ & $30.10-31.35$ & $33.20-33.50$ & sole \\
\hline
\end{tabular}

${ }^{a}$ Only dominant cropping systems are indicated. A.Chu.-Ada Chukallaa; AJTSC-African Juice Tibila Share Company.

belonged to small, private farmers. Each field was visited once. Sampled plants were randomly selected by using a quadrant $(0.5 \times 0.5 \mathrm{~m})$ dropped on specified number of equally spaced paces following an inverted " $X$ " pattern. Having made the pre-set number of quadrants (according to the size of the field), 3 - 5 plants/quadrant showing the suspected disease symptoms, as shown in Figure 1, were sampled.

\subsection{Diseases Assessment}

Disease incidence was assessed by counting the total number of plants having SLB symptoms divided by the total plant population within the quadrant and expressed in percentage. Disease severity was determined by a 0 - 5 visual scale (where: 0: no disease; 1 : minute pinhead size spots, 1 - 10\% diseased leaf area; 2 : 11 - 20\% diseased; 3: 21 - 40\% diseased; 4: breaking of leaves from center, 41 $75 \%$ diseased leaf area; 5 : coalescing lesions with $>75 \%$ diseased area), Sharma [23].

\subsection{Isolation and Pathogenicity Test of the Pathogen}

Small pieces of tissue $(5-10 \mathrm{~cm})$ containing lesions were incubated in moist chambers under light for 4 days at $25^{\circ} \mathrm{C} \pm 2^{\circ} \mathrm{C}$ to induce sporulation and confirm colonization by $S$. vesicarium. After 4 days of incubation, conidial and mycelial masses were purified on to potato dextrose agar (PDA) and incubated for 10 - 16 days at $25^{\circ} \mathrm{C} \pm 2{ }^{\circ} \mathrm{C}$. Cultural, morphological and pathogenicity test were used for identification.

Virulence test of the isolates recovered was carried out on Nafis onion variety. Pure culture of 14-days-old $S$. vesicarium was flooded with sterile tap water and, after gently rubbing with a rubber spatula, the resulting suspensions were filtered through sterile nylon gauze. Concentrations of the conidial suspensions were determined with a haemocytometer, adjusted to $3 \times 10^{4}$ conidia $\mathrm{mL}^{-1}$, Köhl et al. [7] with sterile tap water to inoculate 45 days old seedling in the greenhouse. The inoculated onion plants were kept up to 45 days in pots in the greenhouse at $27^{\circ} \mathrm{C}$ average temprature and $75 \%$ average relative humidity. 


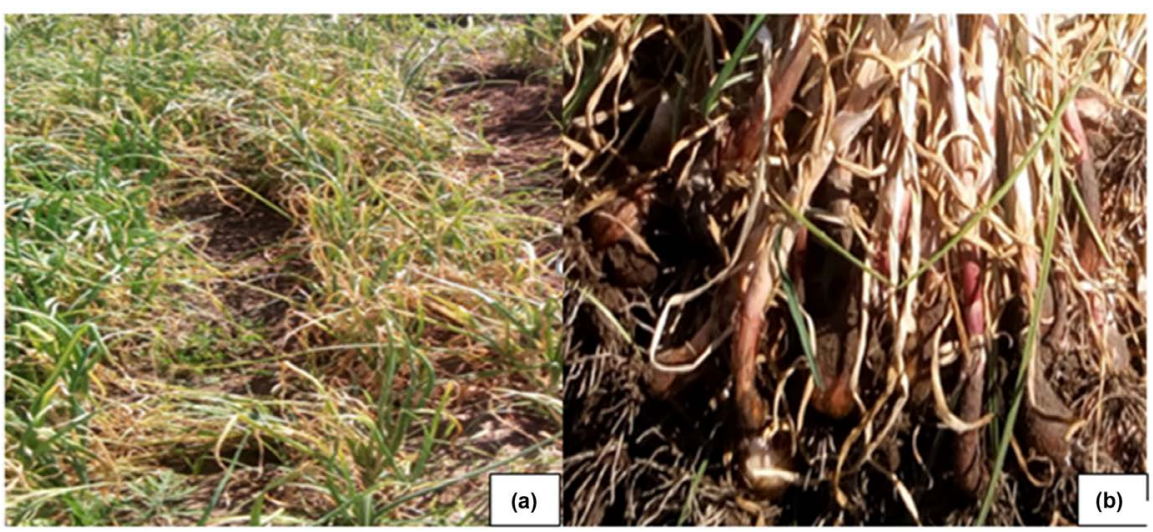

Figure 1. Onion field affected by stemphylium leaf blight: (a) early leaf death and (b) reduced bulb size.

\section{Results and Discussion}

\subsection{Symptoms}

During the survey, the overall look of onion fields affected by the disease is depicted in Figure 1. Early senescence of leaves and flower stalks was observed, especially, when the severity of the disease was high (Figure 1(a)). Besides, reduced bulb size (Figure 1(b)) and associated yield loss was observed whenever matured onion fields were encountered during the survey. This was further confirmed from the communication made with producers during the assessment. Due to this massive appearance of the disease symptoms and maximum production loss, we were even told that farmers in the area call it as "Yeshinkurt Ebola", meaning "Ebola of onion". Specific disease symptoms of small to advanced tan to brown, water-soaked lesions on leaves and onion stalks, advancing to dark-brown to black sporulation and whitish fruiting structure were common (Figures 2(a)-(d)). These symptoms were more obvious on older plants. Overall, the symptoms observed during the survey are similar with symptoms description of SLB by Basallote-Ureba et al. [24].

\subsection{Disease Incidence and Severity}

Severity and incidence of SLB in the surveyed area are summarized in Table 1. Accordingly, the highest (95.2\%) and the lowest (10\%) mean disease incidence was recorded at Jeju and Adama districts, respectively; while the maximum disease severity (4.67) was observed at Dugda. In general, SLB was prevalent in all districts assessed with various range of incidence and severity. According to the farmers, in areas such as Koka, the SLB disease was started to be observed since 2016, which might have been misdiagnosed as purple blotch disease.

\subsection{Identification of the Pathogen from Diseased Leaf Samples}

Cultural, morphological and pathogenic characteristics of the isolates from symptomatic onion leaf specimen revealed the presence of $S$. vesicarium. 


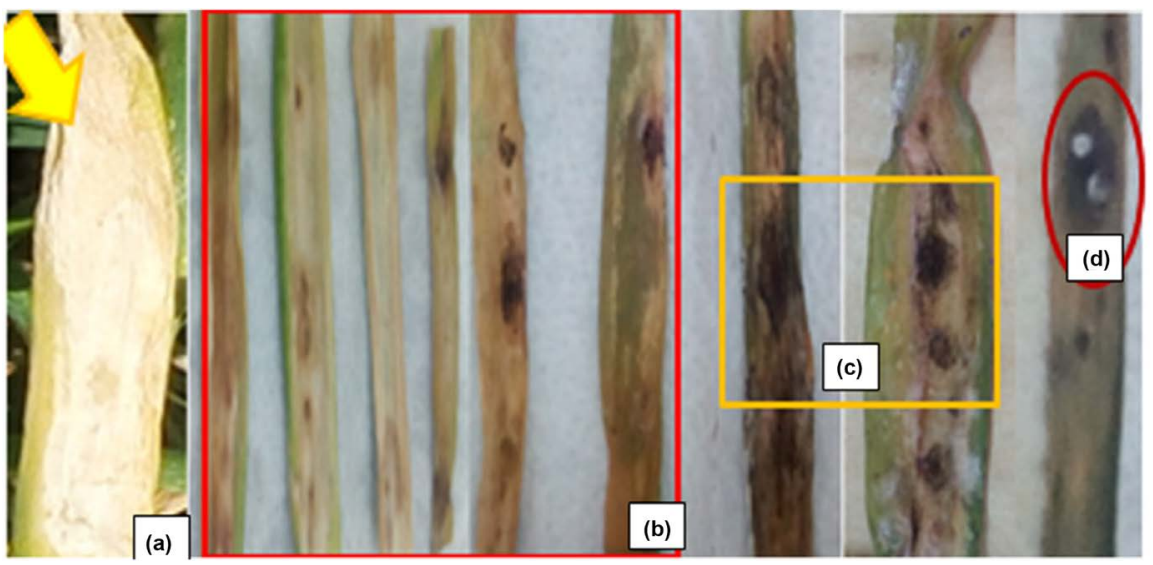

Figure 2. Symptoms of various stages observed during survey: (a) tan spots (lesions); (b) advanced brown spots; (c) brown lesions advanced to black sporulation; (d) advanced black sporulation tuning to whitish fruiting structure, mycelia.

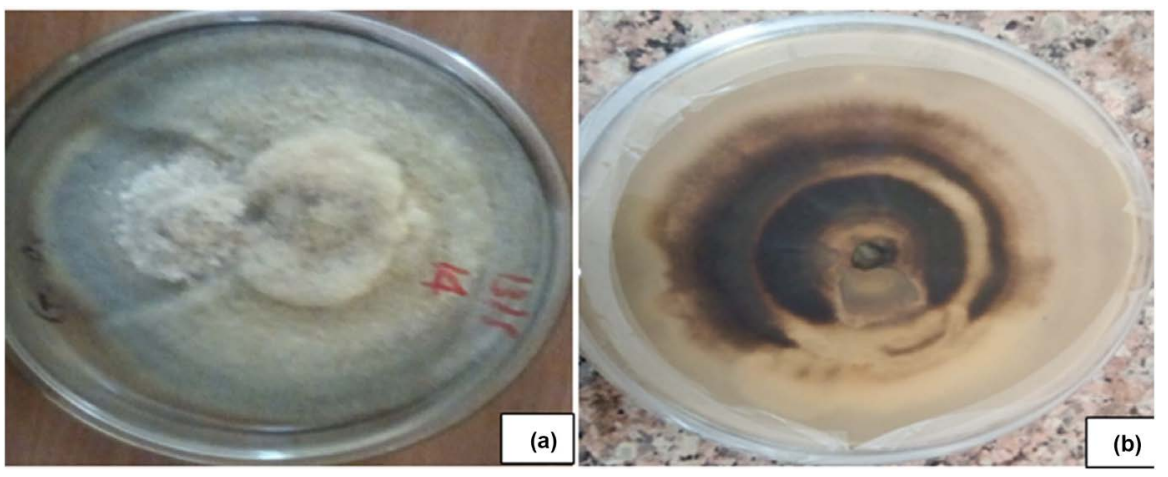

Figure 3. Cultural characteristics (a: front and b: back view) of 13-days-old $S$. vesicarium on PDA media.

\subsection{Cultural and Morphological Characteristics}

The in-face colony color was dirty white to light grey (Figure 3(a)). The reverse colony colors were deep brown, brown and light brown with circular white and brown alternate band growth pattern (Figure 3(b)). This dirty white and brown alternate growth and sporulation have found a distinct feature to $S$. vesicarium colony growth on PDA media. This result is equivalent to pathogen descriptions of Hosna et al. [25]. The conidia were olive-brown, oval to ovoid, oblong and ovoid to oblong, are borne on conidiophores that are pale to brown with dark edges and bands (Figure 4). This is in line with the $S$. vesicarium previous description, Simmon [26]; Basallote-Ureba et al. [24] and Woudenberg et al. [15].

\subsection{Pathogenecity of Stemphylium vesicarium}

Patogenicity test was conducted to confirm whether the pathogen is the primary cause of the disease observed on onion fields during the survey. Periodical assessment (i.e. every week after $1^{\text {st }}$ symptom observation) resulted in small white tan spots starting from 14 days of post-inoculation (Figure 5). The symptoms 

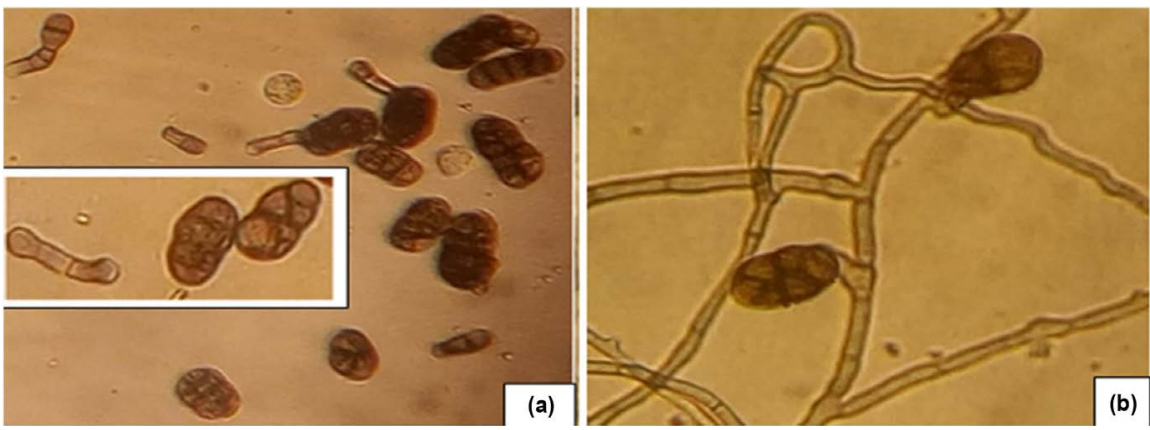

Figure 4. Conidia (a) and Conidiophores (b) of 13-days-old $S$. vesicarium on PDA under $40 \times$ compound microscopy.

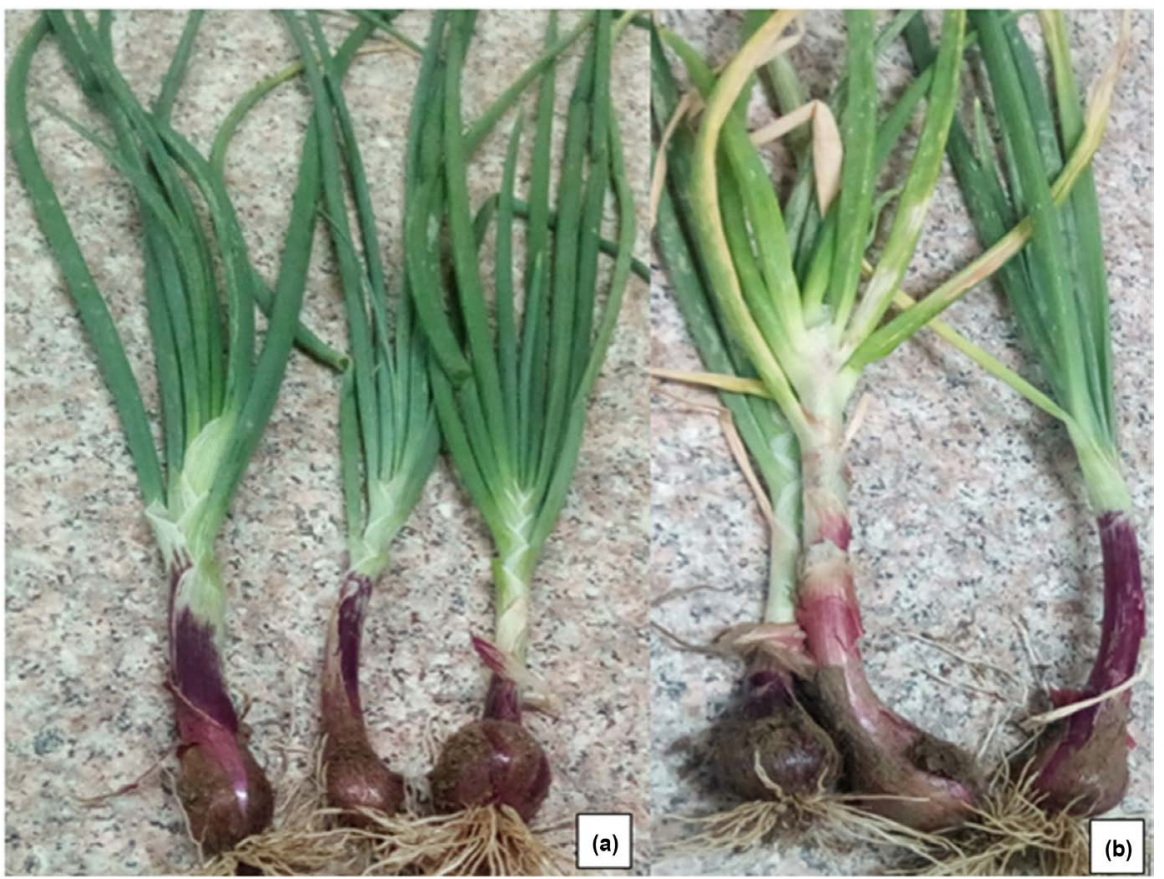

Figure 5. Symptom expression of $S$. vesicarium during pathogenicity test; (a) non-inoculated onion (b) inoculated.

have been intensive and extended to all inoculated plants with in a pot and were as similar to the symptoms observed during the survey. Moreover, successful re-isolation of the pathogen from artifially inoculated symptomatic leaf tissue affirms that the pathogen was pathogenic to onion and that was realy responsible to massive production loss observed during the survey, which the onion farmers in the CRV area call it "Ebola of onion".

\section{Conclusion}

Based on the literature, this is the first report of the occurrence of stemphylium leaf blight (S. vesicarium) on onion in Ethiopia. Complementary work to map its distribution and intensity in the country, determining other putative hosts and the best management options will be relevant to manage the disease. 


\section{Conflicts of Interest}

The authors declare no conflicts of interest regarding the publication of this paper.

\section{References}

[1] CSA (Central Statistical Authority) (2017) Area under Production of Major Crops. Statistical Bulletin, Addis Ababa.

[2] Amin, M., Tadele, S. and Selvaraj, T. (2014) White Rot (Sclerotium cepivorum Berk)-An Aggressive Pest of Onion and Garlic in Ethiopia: An Overview. Journal of Agricultural Biotechnology and Sustainable Development, 6, 6-15. https://doi.org/10.5897/JABSD2013.0210

[3] Suheri, H. and Price, T.Y. (2000) Stemphylium Leaf Blight of Garlic (Allium sativum) in Australia. Australasian Plant Pathology, 29, 192-199. https://doi.org/10.1071/AP00034

[4] Vitale, S., Luongo, L., Galli, M. and Belisario, A. (2017) First Report of Stemphylium vesicarium on Chilli Pepper in Italy. New Disease Reports, 35, 36. https://doi.org/10.5197/j.2044-0588.2017.035.036

[5] Foster, J.M. (2018) Epidemiology and Management of Foliar Diseases in Asparagus (Asparagus officinalis L.). Doctoral Dissertation, University of Guelph, Ontario.

[6] Llorente, I. and Montesinos, E. (2006) Brown Spot of Pear: An Emerging Disease of Economic Importance in Europe. Plant Disease, 90, 1368-1375.

https://doi.org/10.1094/PD-90-1368

[7] Köhl, J., Groenenboom-de Haas, B., Goossen-van de Geijn, H., Speksnijder, A., Kastelein, P., de Hoog, S. and van den Ende, B.G. (2008) Pathogenicity of Stemphylium vesicarium from Different Hosts Causing Brown Spot in Pear. European Journal of Plant Pathology, 124, 151-162. https://doi.org/10.1007/s10658-008-9402-2

[8] Rao, N.R. and Pavgi, M.S. (1975) Stemphylium Leaf Blight of Onion. Mycopathologia, 56, 113-118. https://doi.org/10.1007/BF00472582

[9] Shishkoff, N. and Lorbeer, J.W. (1987) A New Leaf Disease of Onion in New York Caused by Stemphylium vesicariurn. Phytopathology, 77, 1713-1713.

[10] Aveling, T.A. and Naude, S.P. (1992) First Report of Stemphylium vesicarium on Garlic in South Africa. Plant Disease, 76, 426. https://doi.org/10.1094/PD-76-0426E

[11] Aveling, T.A.S. and Snyman, H.G. (1993) Infection Studies of Stemphylium vesicarium on Onion Leaves. Mycology Research, 97, 984-988.

https://doi.org/10.1016/S0953-7562(09)80866-6

[12] Basallote, M.J., Prados, A.M., Pérez, D.A. and Melero-Vara, J.M. (1993) First Report in Spain of Two Leaf Spots of Garlic Caused by Stemphylium vesicarium. Plant Disease, 77, 952. https://doi.org/10.1094/PD-77-0952A

[13] Boiteux, I., Lima, M.F., Sobrinho, J.M. and Lopes, C.A. (1994) A Garlic (Allium sativum) Leaf Blight Caused by Stemphylium vesicarium in Brazil. Plant Pathology, 43, 412-414. https://doi.org/10.1111/j.1365-3059.1994.tb02704.x

[14] Polat, Z., Besirli, G., Sönmez, İ. and Yavuz, B. (2012) First Report of Stemphylium Leaf Blight of Garlic (Allium sativum) Caused by Stemphylium vesicarium in Turkey. New Disease Reports, 25, 29. https://doi.org/10.5197/j.2044-0588.2012.025.029

[15] Woudenberg, J.H.C., Hanse, B., Van Leeuwen, G.C.M., Groenewald, J.Z. and Crous, P.W. (2017) Stemphylium Revisited. Studies in Mycology, 87, 77-103. 
https://doi.org/10.1016/j.simyco.2017.06.001

[16] Brahamanage, R.S., Hyde, K.D., Li, X.H., Zhang, W., Liu, M., Jayawardena, R.S., McKenzie, E.H.C. and Yan, J.Y. (2018) Are Pathogenic Isolates of Stemphylium Host Specific and Cosmopolitan? Plant Pathology \& Quarantine, 8, 153-164. https://doi.org/10.5943/ppq/8/2/7

[17] Miller, M.E., Taber, R.A. and Amador, J.M. (1978) Stemphylium Blight of Onion in South Texas. Plant Disease Reporter, 62, 851-853.

[18] Tomaz, I. and Lima, A. (1986) An Important Disease of Onion Caused by Stemphylium vesicarium (Wallr.) Simmons in Portugal. Horticultural Abstracts, 68, 618.

[19] Lorbeer, J.W. (1993) A Serious Outbreak of Stemphylium Leaf Blight of Onion in New York. In: Proceedings of the 1993 National Onion Research Conference, Cornell University, Ithaca, 32-37.

[20] Llorente, I. and Montesinos, E. (2002) Effect of Relative Humidity and Interrupted Wetness Periods on Brown Spot Severity of Pear Caused by Stemphylium vesicarium. Phytopathology, 92, 99-104. https://doi.org/10.1094/PHYTO.2002.92.1.99

[21] Hausbeck, M.K., Cortright, B.D., Myers, N. and Olsen, L.G. (2005) Optimal Use of Fungicides to Manage Purple Spot and Rust on Asparagus Ferns. 11 th International Asparagus Symposium, Vol. 776, 153-160. https://doi.org/10.17660/ActaHortic.2008.776.18

[22] Wondirad, M., Eshetu, A., Mohammed, Y., Alemu, L., Yaynu, H., Meki, S., Fekede, A., Temam, H. and Adane, A. (2009) Review of Vegetable Diseases Research in Ethiopia. In: Tadesse, A., Ed., Increasing Crop Production through Improved Plant Protection, Volume II, Plant Protection Society of Ethiopia (PPSE), PPSE and EIAR, Addis Ababa, 203-230.

[23] Sharma, S.R. (1986) Effect of Fungicidal Sprays on Purple Blotch and Bulb Yield of Onion. Indian Phytopathology, 39, 78-82.

[24] Basallote-Ureba, M.J., Prados-Ligero, A.M. and Melero-Vara, J.M (1999) Aetiology of Leaf Spot of Garlic and Onion Caused by Stemphylium vesicarium in Spain. Plant Pathology, 48, 139-145. https://doi.org/10.1046/j.1365-3059.1999.00313.x

[25] Hosna, A.C., Nuru, I., Belal, H., Moudood, A., Sayed, M. and Rafiqul, I. (2015) A Comparative Analysis of Culture Media for Optimizing the Mycelial Growth and Sporulation of Stemphylium vesicarium Cause of White Blotch of Onion. Journal of Agricultural Science and Technology, 5, 440-448. https://doi.org/10.17265/2161-6256/2015.06.006

[26] Simmons, E.G. (1985) Perfect States of Stemphylium II. Sydowia, Annales Mycologici Series II, 38, 284-293. 